\title{
Muscutt Misplaced: The Future of Forum of Necessity Jurisdiction in Canada
}

Janet Walker

Osgoode Hall Law School of York University, jwalker@osgoode.yorku.ca

Source Publication:

Canadian Business Law Journal. Volume 48, Issue 1 (2009), p. 135-143.

Follow this and additional works at: https://digitalcommons.osgoode.yorku.ca/scholarly_works (c) (1) $(9)$

This work is licensed under a Creative Commons Attribution-Noncommercial-No Derivative Works 4.0 License.

\section{Recommended Citation}

Walker, Janet. "Muscutt Misplaced: The Future of Forum of Necessity Jurisdiction in Canada." Canadian Business Law Journal 48.1 (2009): 135-143.

This Commentary is brought to you for free and open access by the Faculty Scholarship at Osgoode Digital Commons. It has been accepted for inclusion in Articles \& Book Chapters by an authorized administrator of Osgoode Digital Commons. 


\section{MUSCUTT MISPLACED: THE FUTURE OF FORUM OF NECESSITY JURISDICTION IN CANADA}

So much has been learned about the law of jurisdiction in the seven years since the Muscutt decision ${ }^{1}$ was released that the Court of Appeal for Ontario has decided to consider the possibility of changes to the jurisdictional test it established. ${ }^{2}$ This brief comment offers some suggestions on how the Muscutt analysis might contribute to the evolving law of jurisdiction in Canada.

\section{The Dilemma Faced in Muscutt}

The Muscutt test initially sought to provide a framework of analysis for all cases in which jurisdiction was asserted on the basis of a real and substantial connection. However, the cases before the court were in a special class of their own. In each of the five cases, ${ }^{3}$ jurisdiction was asserted on the basis of Rule 17.02(h), a provision for service outside Ontario "in respect of damage sustained in Ontario arising from a tort, breach of contract, breach of fiduciary duty or breach of confidence, wherever committed". 4 Rule 17.02(h) cases tend to be brought in situations where the only connection to Ontario is that the plaintiffs have come to Ontario from the place where they have suffered harm and they have continued to suffer harm in Ontario.

The appellants in the five cases objected that this did not constitute a real and substantial connection to the forum. In my view, they were right. However, this created a dilemma because the court also could not exercise jurisdiction. At the time, the court accepted the proposition that in cases of service ex juris, absent the parties' consent, where there was no real and substantial connection between the matter and the forum, it would be contrary to the constitutional requirements of the principles of order and fairness to exercise jurisdiction. Having concluded that it should have the discretion to exercise jurisdiction in cases such as these, the court solved the

1. Muscutt v. Courcelles (2002), 213 D.L.R. (4th) 577, 162 O.A.C. 122 (C.A.).

2. In Van Breda v. Village Resorts Ltd. (2008), 60 C.P.C. (6th) 186 (S.C.J.) and Charron Estate v. Bel Air Travel Group Ltd. (2008), 92 O.R. (3d) 608 (C.J.).

3. Muscutt, supra, footnote 1; Leufkens v. Alba Tours International Inc. (2002), 213 D.L.R. (4th) 614 at p. 614, 60 O.R. (3d) 84 (C.A.); Lemmex v. Bernard (2002), 213 D.L.R. (4th) 627 at p. 627,60 O.R. (3d) 54 (C.A.); Sinclair v. Cracker Barrel Old Country Store, Inc. (2002), 213 D.L.R. (4th) 643 at p. 643, 60 O.R. (3d) 76 (C.A.); and Gajraj v. DeBernardo (2002), 213 D.L.R. (4th) 651 at p. 651,60 O.R. (3d) 68 (C.A.). Consolidated costs to all five decisions supra, footnote 1.

4. Rules of Civil Procedure, R.R.O. 1990, Reg. 194, as am. 
dilemma by creating a comprehensive test for cases involving service ex juris that would also include this special class of cases. In my view, this was a mistake.

The resulting eight-factor test has been decried as complex and uncertain. ${ }^{5}$ This is unfortunate in light of the valuable contribution that the judgment has made to the jurisprudence, and the contribution that the analysis could make to the determination of jurisdiction in the special class of cases that prompted its development.

\section{Forum of Necessity Jurisdiction}

Since the time of the Muscutt decision, it has emerged that a court will not necessarily be prevented from exercising jurisdiction merely by reason of the lack of a real and substantial connection between the matter and the forum. Accordingly, even if the appellants in the Muscutt cases were correct that there was no real and substantial connection between their cases and Ontario, it would not necessarily follow that the court could not exercise jurisdiction. This is because there may be a fourth basis of jurisdiction for this special class of cases beyond the three traditional bases: consent, defendant's forum, and real and substantial connection. Perhaps more accurately, it might be said that even though the law of jurisdiction is constitutionally grounded, the Constitution serves as a foundation or a framework for jurisdiction, not a limit to it; and in certain extraordinary situations, the court has a discretion to exercise jurisdiction in cases beyond the three traditional bases.

This discretion exists when the court is called upon to serve as a forum of necessity. The idea that a court should be available to serve as a forum of necessity is relatively new in Canada. It was drawn from art. 3 of the Swiss Private International $\mathrm{Law}^{6}$ and it was included in art. 3136 of the Civil Code of Quebec, ${ }^{7}$ and in s. 6 of the Court

5. Joost Blom and Elizabeth Edinger, "The Chimera of the Real and Substantial Connection Test" (2005), 38 U.B.C. L. Rev. 373; Stephen Pitel and Cheryl Dusten, "Lost in Transition: Answering the Questions Raised by the Supreme Court of Canada's New Approach to Jurisdiction" (2006), 85 Can. Bar Rev. 61; Jean-Gabriel Castel, "The Uncertainty Factor in Canadian Private International Law" (2007), 52 McGill L.J. 555; Tanya Monestier, "A Real and Substantial Mess: The Law of Jurisdiction in Canada” (2007), 33 Queen's L.J. 179. Some provinces have since enacted statutes for jurisdiction based on the Uniform Law Conference of Canada, "Uniform Court Jurisdiction and Proceedings Transfer Act" Proceedings 1994 (cJPTA).

6. Article 3 provides "Lorsque la présente loi ne prévoit aucun for en Suisse et qu'une procédure à l'étranger se révèle impossible ou qu'on ne peut raisonnablement exiger qu'elle y soit introduite, les autorités judiciaires ou administratives 
Jurisdiction and Proceedings Transfer Act, ${ }^{8}$ and it finds general support in art. 6 of the European Convention on Human Rights, which proscribes a denial of justice. ${ }^{9}$ A court may exercise jurisdiction as a forum of necessity even though none of the traditional bases of jurisdiction exists when the proceedings cannot possibly be instituted elsewhere or where the institution of such proceedings elsewhere cannot reasonably be required.

\section{The Standards for Forum of Necessity Jurisdiction}

If the Court of Appeal accepts that the Constitution does not constrain it from exercising discretion to serve as a forum of necessity, a host of important questions arise about the way in which this discretion should be exercised. Despite the fact that provisions for forum of necessity jurisdiction are now in force in a growing number of provinces across Canada, ${ }^{10}$ there has been scant consideration of the standards that should apply to its exercise.

We are fortunate, therefore, to be able to draw on the thoughtful analysis contained in the Muscutt judgment to begin to fashion standards suited specifically to these cases. Although the Muscutt test was initially directed at the full range of cases of service ex juris, it was nevertheless developed in a context that was sensitive to the considerations affecting the special class of cases before it, and it contains much to offer to the analysis of the standards that should apply to them.

The usefulness of some of the general features of the Muscutt analysis is immediately apparent. First, the court emphasized the need for a flexible, multi-factored, fact-specific analysis, which is appropriate for a narrow class of exceptional cases that have yet to

suisses du lieu avec lequel la cause présente un lien suffisant sont compétentes.": 291 Loi fédérale sur le droit international privé (Switzerland, 1987).

7. Article 3136 provides "Bien qu'une autorité québécoise ne soit pas compétente pour connaitre d'un litige, elle peut, néanmoins, si une action à l'étranger se révèle impossible ou si on ne peut exiger qu'elle y soit introduite, entendre le litige si celui-ci présente un lien suffisant avec le Québec.": R.J.Q. 1991, c. 64, art. 3136.

8. Section 6 provides "A court that under section 3 lacks territorial competence in a proceeding may hear the proceeding despite that section if it considers that: (a) there is no court outside [enacting province or territory] in which the plaintiff can commence the proceeding; or (b) the commencement of the proceeding in a court outside [enacting province or territory] cannot reasonably be required.": CJPTA, supra, footnote 5 , at p. 7 .

9. Lubbe v. Cape Plc, [2000] 2 Lloyd's Rep 383 (H.L.).

10. CJPTA, S.B.C. 2003, c. 28; CJPTA, S.S. 1997, c. C.41.1; CJPTA, S.N.S. 2003 (2nd Sess.), c. 2; Alberta Law Reform Institute, Final Report No. 94, Enforcement of Judgments (September 2008), online: <www.law.ualberta.ca/alri/docs/ FR94.pdf > . 
receive much consideration. Well-established areas of jurisdictional analysis may be better served by more standardized common law tests or by codified provisions, but it is helpful to consider a newly defined class of cases in a framework that is mindful of first principles and open to the possibility that new patterns of analysis may emerge. Although the court was criticized for failing to maintain the traditional distinction between the rule-based approach that is associated with jurisdiction simpliciter determinations, and the discretionary approach that is associated with forum non conveniens determinations, a discretionary approach is appropriate for a kind of jurisdiction that is to be exercised sparingly and only in exceptional situations. The structure of the Civil Code of Quebec, which places forum non conveniens and forum of necessity next to one another in arts. 3135 and 3136, and which treats them as departures in both directions from the basic jurisdictional standards, seems also to suggest that both departures should be treated as discretionary.

Second, the first four of the Muscutt factors address the circumstances of both parties. This is important in this special area of jurisdiction. In cases of jurisdiction based on consent, ${ }^{11}$ a court may rely on the parties to resolve issues of their particular circumstances, and in cases involving local defendants, a court may rely on a presumption in favour of jurisdiction, subject to a showing that some other forum is clearly more appropriate. ${ }^{12}$ However, no such presumption in favour of jurisdiction supports cases of service out, ${ }^{13}$ and there would seem to be a presumption against jurisdiction in cases of forum of necessity. Accordingly, in assessing cases of forum of necessity jurisdiction courts will be concerned to ensure both that the obstacles to commencing proceedings elsewhere are sufficiently serious to justify it serving as a forum of necessity, and that trial in Ontario will not come at the expense of the defendant's ability to present its defence.

Finally, the other four of the Muscutt factors address the implications of jurisdictional determinations for other potential parties to the suit and for broader concerns of comity. This last feature of the analysis will be crucial to the development of the law of jurisdiction. As the process of globalization encourages the involvement in international dealings of more and more ordinary persons who will have difficulty commencing proceedings

11. Z.I. Pompey Industrie v. Ecu-Line N.V., [2003] I S.C.R. 450, 224 D.L.R. (4th) 577.

12. Amchem Products Inc. v. British Columbia (Workers' Compensation Board), [1993] I S.C.R. 897, 102 D.L.R. (4th) 96.

13. Frymer v. Brettschneider (1994), 115 D.L.R. (4th) 744,19 O.R. (3d) 60 (C.A.). 
elsewhere,${ }^{14}$ the court will need to be mindful of the implications for comity of the standards it sets for this expanded jurisdiction. Placed in this context, the Muscutt analysis could make an invaluable contribution to the development of the law of jurisdiction in Canada in the years ahead.

\section{The Muscutt Factors and Forum of Necessity Jurisdiction}

With this in mind, it is possible to revisit the current framework of factors to suggest how they might be tailored to suit the specific concerns arising in forum of necessity cases.

The first two factors - the connection between the forum and the plaintiff's claim, and the connection between the forum and the defendant - could serve as important threshold considerations in deciding whether jurisdiction should be determined through the more familiar real and substantial connection analysis or on the extraordinary ground of forum of necessity.

Where "the connection between the forum and the plaintiff's claim" is of the kind that, if the matter were subject to regulation, it would properly be subject to regulatory standards promulgated in the forum, then it is not necessary to consider whether the court should serve as a forum of necessity. Jurisdiction should be decided on the basis of the traditional "real and substantial connection/forum non conveniens" analysis, just as it once would have been in other cases of service outside the jurisdiction and as it is now decided pursuant to the CJPTA. Similar considerations would apply to cases where "the connection between the forum and the defendant" is of the kind that made it reasonably foreseeable that the harm caused by the defendant's actions would be suffered in the forum. ${ }^{15}$ For example, cases of products liability in which the product is manufactured elsewhere but shipped into the forum for use by consumers in the forum are generally thought to be within the court's jurisdiction. ${ }^{16}$

14. Janet Walker, "Beyond Big Business: Contests between Jurisdictions in a Vertically Integrated Global Economy" (November 2000) (paper presented at the Law Society of Upper Canada, Civil Litigation Forum, Toronto).

15. In the paradigm scenario described in Muscutt, an Ontario resident suffers injury abroad and returns home enduring further pain and suffering, receiving medical treatment, and suffering loss of income and amenities of life. In two of the Muscutt cases, the matter concerns the tourism industry operating in other parts of the world, raising the feasibility of providing for the special costs associated with hosting patrons from Ontario who may seek recovery in Ontario courts.

16. Moran v. Pyle National (Canada) Ltd., [1975] 1 S.C.R. 393 at pp. 408-409, 43 D.L.R. (3d) 239. 
Assuming that the case before the court is one in which there is but a tenuous connection to the forum and the harm has not been the result of actions that the defendant could reasonably foresee as creating the risk of harm in the forum, the court will be in a position to consider whether it should exercise jurisdiction as a forum of necessity. In doing so, the third and fourth factors - "unfairness to the defendant in assuming jurisdiction" and "unfairness to the plaintiff in not assuming jurisdiction"- would form the focus of much of the analysis.

The fourth factor - concerning fairness to the plaintiff - reflects the basic requirement of forum of necessity jurisdiction: that "proceedings cannot possibly be instituted elsewhere" or that "the institution of such proceedings elsewhere cannot reasonably be required". There will necessarily be a heavy onus on the plaintiff in persuading a court to exercise jurisdiction in cases where the traditional bases do not exist. Accordingly, the need to demonstrate a good arguable case, as is traditionally included as a threshold merits test in cases of service outside the jurisdiction, could become an integral feature of the analysis for such cases.

Furthermore, in assessing whether there is a good arguable case, there may bejustification for the court to go beyond what is ordinarily permitted under the rules ${ }^{17}$ to hear argument on questions of the implications of applying a relevant foreign law. If the reason that the plaintiff has not instituted proceedings in the place where the harm occurred is that the law of that place does not afford recovery of the nature or the extent available in Ontario, the court may be reluctant to facilitate the plaintiff's choice of forum. The drafters of the forum of necessity provisions were careful to provide that it should be exercised when "proceedings cannot possibly be instituted elsewhere"- not merely when the plaintiff cannot obtain elsewhere the kind of recovery that might be available in the forum under local law.

Turning to the third factor - concerned with fairness to the defendant - the court will want to be mindful, as it was in the Muscutt analysis, of concerns about the way in which exercising jurisdiction may affect the ability of the defendant to present its defence. For individual defendants, it may be unreasonable to expect them to travel great distances to Ontario and to retain counsel in Ontario to defend against the claim in a legal system that is foreign to them. For

17. Rule 17.06 of the Rules of Civil Procedure, R.R.O. 1990, Reg. 194 requires jurisdictional determinations to be made before the statement of defence is delivered - before potentially dispositive questions of applicable law can be raised. 
other defendants, there may be impediments to making witnesses or evidence available outside the forum where the cause of action arose. On such difficult occasions, despite the potential for the court to serve as a forum of necessity, it may not always be appropriate for it to do so. In some situations, the impediments faced either by plaintiffs or by defendants may be overcome by new technologies or by new forms of interjurisdictional cooperation. In other situations, where routine patterns emerge, it may become common to obtain insurance coverage to safeguard against such eventualities. Not all jurisdictional questions can be answered by amending the test for jurisdiction.

The fifth factor in Muscutt - the involvement of other parties to the suit-raises jurisdictional considerations that are often overlooked. Like the necessary counterpart to rule $17.02(\mathrm{~h})$, rule 17.02(o), which provides for jurisdiction over a person "who is a necessary or proper party to a proceeding properly brought against another person served in Ontario" 18 might justify an exercise of jurisdiction on the basis that the institution of proceedings elsewhere cannot reasonably be required. ${ }^{19}$ While exercising jurisdiction merely by reason of the fact that the defendants a re necessary parties may not be justified on grounds of real and substantial connection, ${ }^{20}$ it could sometimes be consistent with the constitutional requirements of the principles of order and fairness to do so. As was noted in Muscutt, courts will need to be vigilant to ensure that the availability of jurisdiction on this ground does not serve to encourage manipulative joinder in which local defendants are named simply to gain access to defendants outside the forum.

Finally, the court in Muscutt sensibly prescribed the consideration of the broader implications for comity of jurisdictional determinations in extraordinary cases such as these. The sixth and eighth factors - "whether the court would be willing to recognize and enforce an extra-provincial judgment rendered on the same jurisdictional basis" and "comity and the standards of jurisdiction, recognition and enforcement prevailing elsewhere"- are important factors in assessing whether in all events the exercise of jurisdiction on this basis would be overreaching. While these factors seem more likely to be the subject of argument rather than evidence, they will be

18. Rules of Civil Procedure, R.R.O. 1990, Reg. 194.

19. McNichol Estate v. Woldnik (2001), 13 C.P.C. (5th) 61, 150 O.A.C. 68 (C.A.), leave to appeal to S.C.C. refused [2002] 2 S.C.R. viii.

20. Like "damages sustained in the jurisdiction" this ground too was omitted from those endorsed by the Uniform Law Conference of Canada in the CJPTA as presumptive real and substantial connections: CJPTA, supra, footnote 5. 
particularly valuable in cases in which the court is called upon to revisit jurisdictional standards in light of evolving standards elsewhere. $^{21}$

On a supplementary note, the original Muscutt group of five cases included an interprovincial case, thereby prompting the inclusion of the seventh factor (whether the case is interprovincial or international). However, it seems that interprovincial cases are fundamentally different in ways that could cause the other factors to be assessed differently as well, and the concerns that they raise may be better addressed by other means. For example, in the Muscutt case itself, conventional pleading protocols tended to obscure key facts regarding the involvement of insurers, such as the fact that the defendants' coverage required the insurer to defend claims wherever they were brought in Canada.

A similarly pressing concern continues in the jurisprudence on whether medical professionals should be required to respond to claims of medical malpractice in provinces other than those where the care was given but where their injured patients subsequently choose to reside. ${ }^{22}$ Given the special nature of governmental health coverage and medical malpractice coverage in Canada, and the constitutional guarantees of mobility, this may be yet another systemic question that should be addressed by industry-wide or sector-wide solutions rather than through ad hoc jurisdictional determinations. In all events, operating as they do within a federal system, interprovincial cases may benefit from the mechanisms for transfers of proceedings (and parts of proceedings) that are becoming available under the CJPTA where it has been enacted, or from other forms of court-to-court cooperation that are being pioneered in the areas of family law and insolvency.

21. As has occurred in situations such that considered in Bouzari v. Iran (2004), 71 O.R. (3d) 675,243 D.L.R. (4th) 406 (C.A.), leave to appeal to S.C.C. refused 246 D.L.R. (4th) vii.

22. Examples of such cases include Penny (Litigation Guardian of) v. Bouch, 2009 NSCA 80; and MacDonald v. Lasnier (1994), 21 O.R. (3d) 177 (Gen. Div.); JeanJacques v. Jarjoura, [1996] O.J. No. 5174 (QL) (Gen. Div.); Dennis v. Salvation Army Grace General Hospital (1997), 156 N.S.R. (2d) 372, 14 C.P.C. (4th) 207 (N.S.C.A.), leave to appeal to S.C.C. refused 63 N.S.R. (2d) $79 n$; Oakley v. Barry (1998), 158 D.L.R. (4th) 679, 166 N.S.R. (2d) 282 (C.A.), leave to appeal to S.C.C. refused 175 N.S.R. (2d) $400 n$; Bulloch-Macintosh v. Browne, [1998] O.J. No. 5684 (QL) (Gen. Div.); O'Brien v. Canada (Attorney General) (2002), 210 D.L.R. (4th) 668, 201 N.S.R. (2d) 338 (N.S.C.A.), leave to appeal to S.C.C. refused 217 D.L.R. (4th) vi; Warner v. Edmonton General Hospital, [2008] O.J. No. 3252 (QL), 169 A.C.W.S. (3d) 542 (S.C.J.). 


\section{Muscutt Re-engaged}

In sum, the first two Muscutt factors could help courts to determine whether jurisdiction should be assessed on forum of necessity grounds or on the basis of a real and substantial connection. Where there was no real and substantial connection between the forum and either the plaintiff's claim or the defendant, the court would turn to the third and fourth factors to determine whether in view of the circumstances of the parties it should consider serving as a forum of necessity. Where the circumstances of the parties suggest that it should do so, it would consider the sixth and eighth factors to determine whether the implications for comity nevertheless militate against the exercise of jurisdiction. The fifth factor, "the involvement of other parties to the suit", reflects a possible reason in addition to access to justice for the court to serve as a forum of necessity (i.e., the avoidance of multiplicity); and, despite the inclusion of the seventh factor, it seems unlikely for interprovincial cases to raise the same kinds of concerns served by other cases warranting the exercise of forum of necessity jurisdiction.

Although it was ahead of its time, understood in this way, the Muscutt analysis could make a strong contribution to the standards that will need to be developed in the years ahead for forum of necessity jurisdiction. 